\title{
Revisiting the Effect of Financial Development on Economic Growth after the 2008 Global Financial Crisis
}

\author{
Sinem Celik Girgin, Hong-Oanh Nguyen", Thanasis Karlis \\ Department of Maritime and Logistics Management, Australian Maritime College, University of Tasmania, Australia
}

Copyright $\bigcirc 2017$ by authors, all rights reserved. Authors agree that this article remains permanently open access under the terms of the Creative Commons Attribution License 4.0 International License

\begin{abstract}
A growing body of theoretical and empirical literature analyses the relationship between finance and economic growth. The relationship has been strongly supported by many empirical analyses. However, the 2008 Global Financial Crisis (GFC) and the significantly improved econometric techniques made scholars to revisit this relationship. The main motivation of this paper is to empirically revisit the relationship between financial development and economic growth, especially one under the effect of the world's greatest financial crisis since the Great Depression. In this study, both fixed effect and dynamic panel data analysis are conducted by using 147 countries over the period of 2000-2013. The analysis results prove the destructive effect of the GFC on the relationship between financial development and economic growth. Also, the finding showed that the effect of traditional financial development proxies has reduced after the crisis.
\end{abstract}

Keywords Economic Growth, Financial Development, Global Financial Crisis, Panel Data

\section{Introduction}

The role of financial development in economic growth has received gradually increased attention since the early 1900 s $[1,2]$ Even today, the much debated question is whether financial development has a significant effect on economic growth, or whether financial development is primarily led by economic growth [3]. Many scholars, such as Gelb [4], Greenwood and Jovanovic [5], King and Levine [6], Levine [7], [8] provided empirical evidence that there is a strong relationship between financial development and economic growth. The theoretical and empirical rationale behind the financial development and economic growth had been actually explained by these authors. Furthermore, the proxies were defined to measure this relationship and these are applied by many following scholars to measure different set of sample groups [9].

However, the recent economic-financial crisis, 2008 Global Financial Crisis (GFC), has renewed the attention on whether the financial development still promotes economic growth or not [10-13]. The GFC holds significant importance among other worldwide crisis due to its contagion and speed of spread. It was well regarded as the most destructive and complex crisis since the Great Depression of 1929. In both crises, although their origin was in the United States, they had widespread effects over industrialised countries, as well as in a large number of developing and emerging economies. Almost a decade after the crisis, the effect of the GFC on economies still remains. The World Economic Outlook Report of IMF [14] reports that global growth rate is still far below the expectations. Although advanced economies are expected to show a gradual increase in economic growth rate, the emerging market and developing economies are still in growth slowdown and expected to show slower growth in 2016.

The destructive effect of the GFC on economies and on the financial development needed to be explained by the researchers. Initially, the reasons and consequences of the GFC have been studied right after the crisis through different approaches. The similarities with Great Depression, 1929 have been discussed by scholars, such as, Almunia, Benetrix [15], Claessens, Ayhan-Kose [16]; the causes and responses have been discussed by the European Economic and Monetary Union, EMU [17] and by many scholars, such as, Akyüz [18], Crotty [19] Dungey, Dwyer [20] Luchtenberg and $\mathrm{Vu}$ [21]. However, the traditional financial development proxies [6], which are widely applied by scholars to measure the financial development effect on economies before the GFC, have not been examined to revisit its significance after the GFC. 


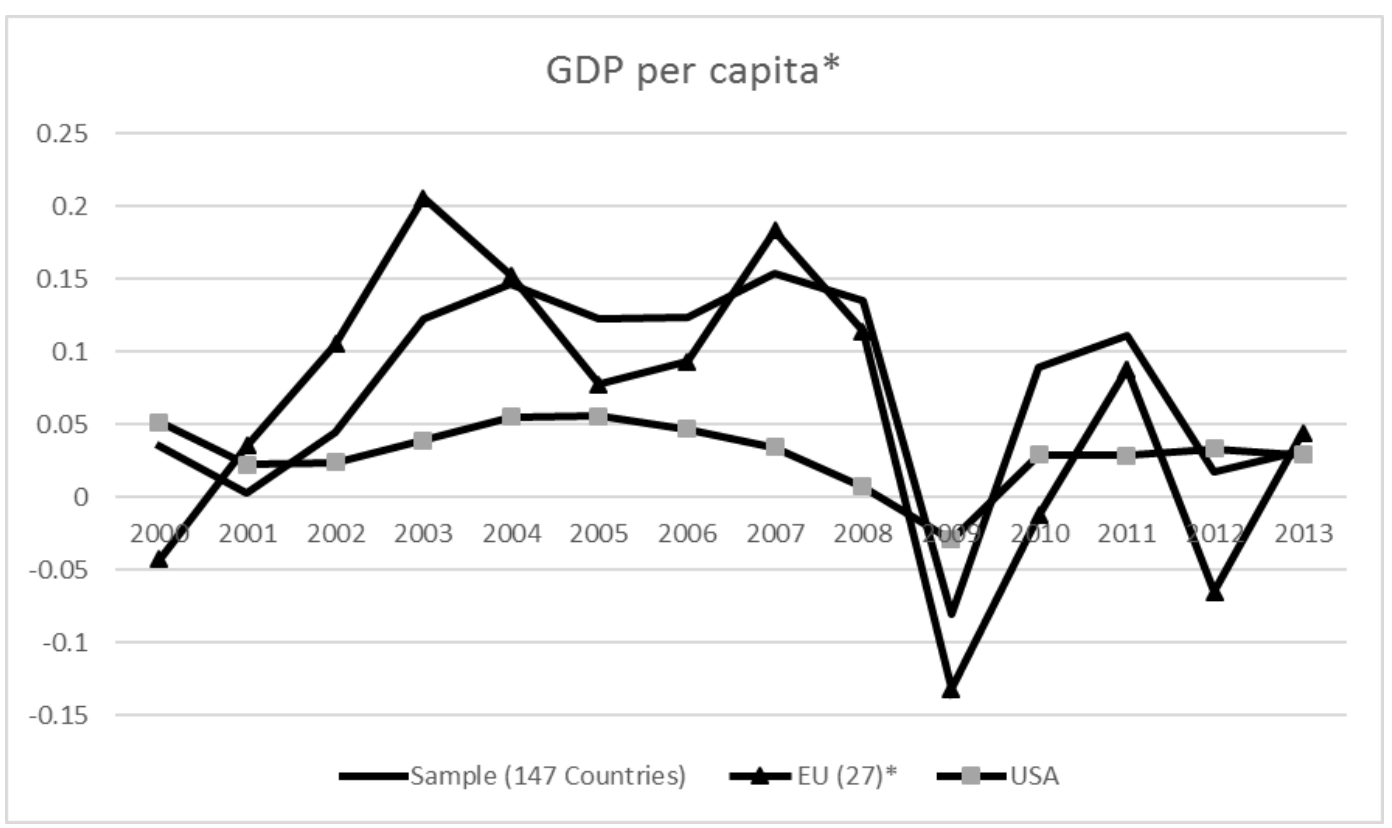

*27 European countries are part of the sample, Luxemburg is eliminated since it does not provide available data.

European Union countries are listed from official website of European Union https://europa.eu/european-union/abouteuropa_en

${ }^{\ddagger}$ GDP per capita is in natural logarithm form.

Figure 1. GDP ${ }^{¥}$ per capita

Taken together, the GFC had a significant and negative effect on financial markets and economic growth of nations. Its effect on stock markets is still ambiguous ${ }^{1}$, but its destructive effect on the banking sectors is observable. The regression results in the banking sector are consistent and are the focus of this paper. Before discussing the previous empirical and theoretical literature on financial development and economic growth nexus, it seems appropriate to consider briefly the economic growth and banking sector indicators for the period 2000-2013.

The first economic indicator is GDP per capita growth which has been decreased to negative during the peak time of crisis. Surprisingly, although the GFC started in the US financial markets, European Union countries recorded a lower GDP per capita growth than the USA in 2009.

In this paper, we used three of the traditional financial measures, Liquid Liabilities, Commercial vs. Central Bank and Private Credit. These three variables fluctuated during the crisis, as indicated in Figures 2, 3, and 4 respectively. Figure 2 illustrates the liquid liabilities defined as currency plus demand and interest bearing liabilities of banks and non-bank financial intermediaries as a percentage of GDP for the sample period for the sample data, 147 countries, EU countries and the USA. The ratio of liquid liabilities to GDP is mostly accepted as an indication of financial depth used in the literature by Goldsmith [22], and King and Levine [6] among others.

1 The stock market analysis for the same period, 2000-2013, for the sample of 80 countries has been undertaken. However, the result is ambiguous and therefore it is not reported in this paper. Regression results can be shared, if requested.
Figure 3 illustrates the Private Credit defined as credit issued by deposit money banks and other financial institutions to the private sector as a percentage of GDP. Figure 4 illustrates the Commercial vs Central bank credit defined as the commercial bank assets divided by the commercial bank plus central bank assets. This measures the relative importance of commercial banks vs. central banks in allocating savings. Presumably, commercial banks seem more likely to provide the type of risk sharing and information services emphasised in recent theoretical models than central banks [9].

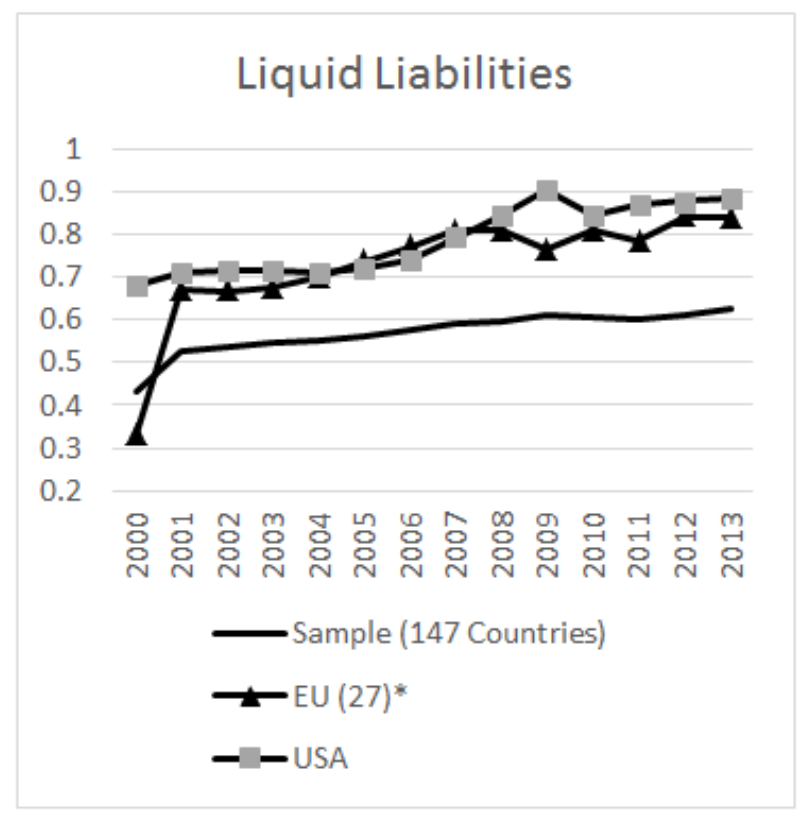

Figure 2. Liquid Liabilities 


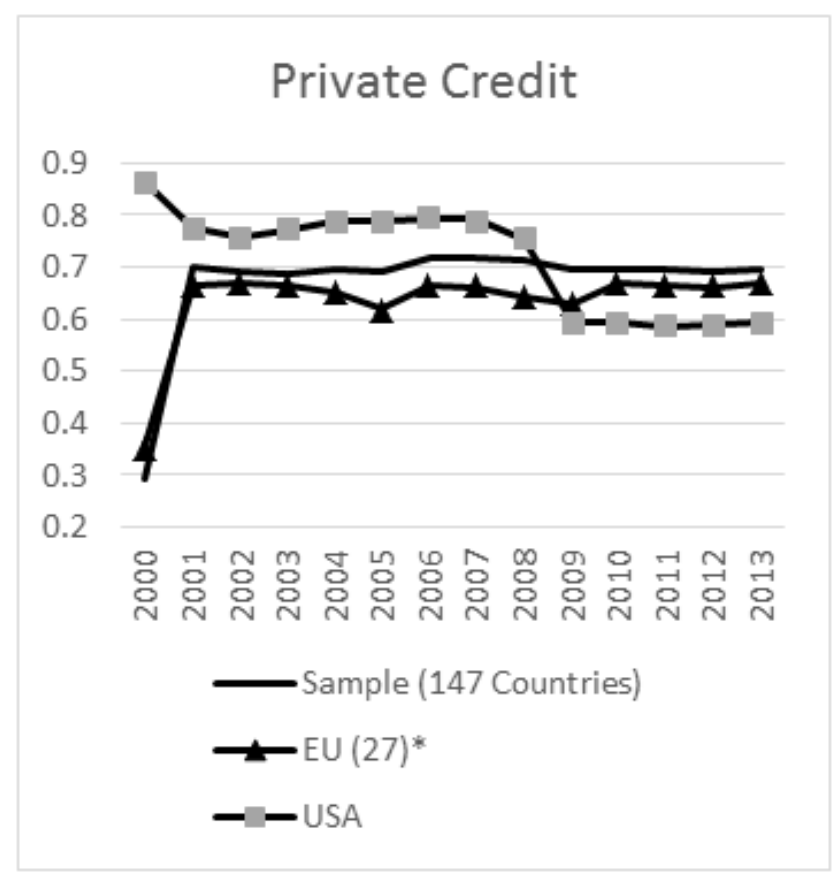

Figure 3. Private Credit

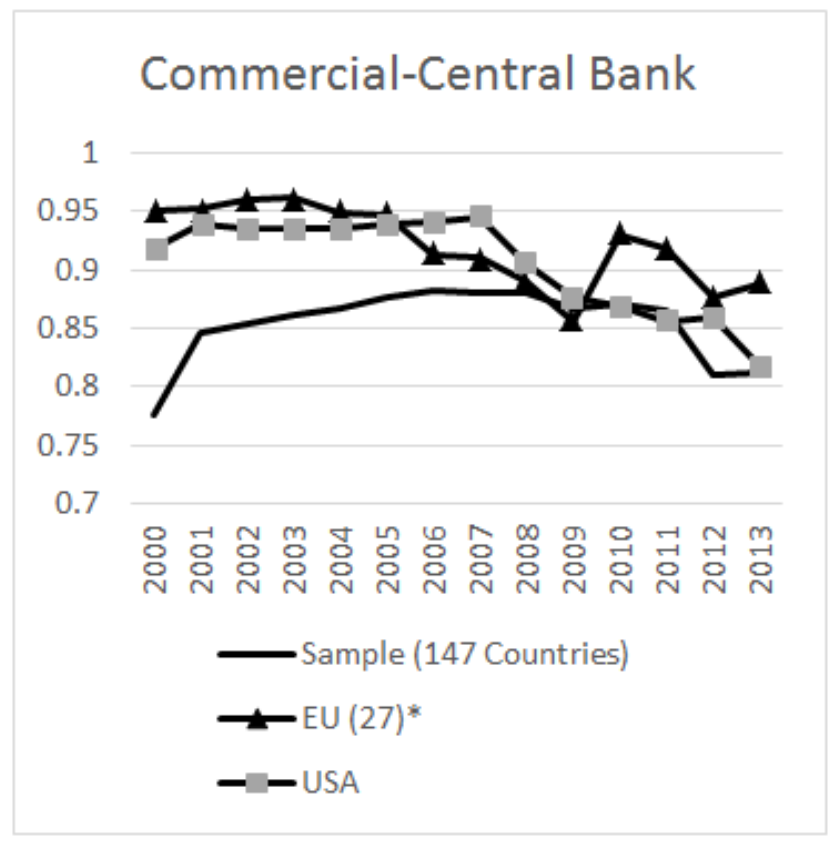

Figure 4. Commercial vs. Central Bank

The aim of this paper is to revisit the causal relationship between financial development and economic growth through the traditional financial variables [6] by focusing on the period between 2000-2013 before and after the GFC using a broad sample of 147 countries. The modified version of dynamic panel data, Arellano and Bover [23] and Blundell and Bond [24] will be used to eliminate the potential weakness of lagged levels. Furthermore both fixed and dynamic panel data analysis will be conducted to draw implications for economic management and future research.

There are a number of contribution of this paper. First, after the GFC, the financial development and economic growth relationship has not been analyzed with broad sample of data in order to reveal the GFC effect on economies.

Second, the post GFC dummy variable is used to capture the GFC effect by comparing before and after period of crisis.

Third, in terms of the estimation techniques, there are two contributions. First, the modified version of dynamic panel data, Arellano and Bover [23] and Blundell and Bond [24], has been used to eliminate the potential weakness of lagged levels. Second, the fixed panel data and dynamic panel data both applied to the sample and their results compared to investigate potential differences.

The rest of the paper is divided into five main sections. Section II provides a brief literature review. Section III then explains the choice of models for the empirical analysis as well as the methodology employed on and data sources. Section IV discusses the major findings from the regression results. The paper concludes with some brief comments in the final section $\mathrm{V}$.

\section{Literature Review}

Bagehot [1], and Schumpeter [2], visionary scholars shed the light on the relationship in terms of financial institutions, specifically banks. Especially, Schumpeter [2] is closely followed by many scholars; such as King and Levine [6] who applied Schumpeter's thought in their seminal paper.

Contrary to attention on the role of financial development in channeling economic growth, Robinson [3] contended that finance simply follows economic growth and Lucas [25] stated that the finance is a "badly over-stressed" issue. He assumed that the financial sector has no impact on growth. However, the finance-growth nexus has received renewed interest in the endogenous growth literature developed since the 1980s [26]. A growing body of empirical studies on financial development and economic growth relationship emerged. The innovative and seminal work of King and Levine [6] used a set of financial proxies ${ }^{2}$ to measure the effect of financial development on economic growth in 80 countries over the period 1960 to 1989 . They found that the financial development proxies are robustly correlated with future rates of economic growth, physical capital accumulation, and economic efficiency improvements. The financial development proxies used by King and Levine [6], have been applied by many scholars in various financial studies $[7,11,12,27-30]$

In addition, before the GFC, Levine [7] reviewed theoretical and empirical works on the relationships between

2 Financial development proxies are LLY, the ratio of liquid liabilities to GDP; BANK, deposit banks relative to the central bank in allocating domestic credit; PRIVATE, credit issued to nonfinancial private firms divided by total credit (excluding credit to banks); and PRIVY, credit issued to nonfinancial private firms divided by GDP. In this paper, LLY, BANK and PRIVATE are used. 
the operation of the financial system and economic growth. $\mathrm{He}$ stated that the vast majority of empirical studies including firm-level studies, industry-level studies, individual country level studies, time-series studies, panel-investigations, and broad cross-country comparisons, show a strong and robust link between the functioning of the financial system and the long-run economic growth.

The literature before the GFC proves that there is a substantial body of studies that strongly support the link between financial development and economic growth. However, the GFC disrupted the link and so it has received increased attention to re-examine the financial development and economic growth nexus. Unfortunately, the empirical studies could not confirm the positive nexus between financial development and economic growth within the GFC period from 2008 to 2015. Jailani and Masih [30] analysed the causality direction of financial development and economic growth by applying the Autoregressive Distributed Lag method in Singapore from 1970 to 2013 by utilising a set of financial development proxies similar to those used by King and Levine [6] in their study. In addition to the proxies used by King and Levine [6], Jailani and Masih [30] used gross national expenditure, gross fixed capital formation and foreign direct investment. They found that financial development had no impact on the economic growth of Singapore in the long-run. The finding was supported by Musta [12]'s study. Particularly, he studied the role of financial development through commercial lending in economic growth of Albania from 1994 to 2015 by considering destructive effect of the GFC. The author ran a time series regression with GDP per capita growth as a dependent variable and domestic credit provided by the banking sector and general government final consumption expenditure as independent variables. He found that the financial expansion appeared to have a negative effect on the economic growth of Albania within the specified time span. The author asserted that the main reason for this negative relationship is a misallocation of capital away from efficient opportunities because of a high number of non-performing loans on the banks' balance sheets.

On the other hand, after the GFC, Aydin and Malcioglu [11] analysed the finance-economic growth nexus in OECD countries by applying similar proxies with those of King and Levine [6] over the period from 1980 to 2014 . They applied the panel causality test to investigate causality between the financial development and the economic growth. Their findings showed the existence of a causality relationship between the financial development and the economic growth for the countries chosen, however, they did not find a causality relationship between the economic growth and the financial development. They emphasised that effective financial markets promote economic development by increasing savings and reallocating investment opportunities.

In this paper, the relationship between financial development and economic growth will be analysed based on King and Levine [6] study. In their study, they provided empirical evidence that higher levels of financial development are significantly and robustly correlated with faster current and future rates of economic growth, physical capital accumulation, and economic efficiency improvements King and Levine [6]. In the current study, this relationship and is examined in a form of the following hypothesis test:

Hypotheses

$H_{0}$ : There is a positive relationship between financial development and economic growth

$H_{1}$ : There is a negative or no relation between financial development and economic growth

\section{Theoretical Model and Estimation Techniques}

\subsection{Model and Data}

With reference to the aim of this paper, the relationship between the financial development and the economic growth will be analysed by applying the traditional King and Levine [6] variables ${ }^{3}$ in order to examine the effect of financial development on growth under the impact of the GFC.

The theoretical model is based on an endogenous growth theory proposed by Arrow [33], Uzawa [34] and Sheshinski [35] and more recently studied by Romer [36], Lucas [25] and Rebelo [37]. In endogenous growth theory includes human capital which assumes that diminishing returns does not apply to this broader class of capital and therefore economic growth will continue [38]. Besides using recent growth model, we used the model proposed by Odedokun [39]. The author proposed a model based on conventional neoclassical one sector production function where financial development constitutes an input. The theoretical form of the model is as follows:

$$
Y_{i t}=f\left(L_{i t}, K_{i t}, H_{i t}, F_{i t}\right),
$$

where variables represent the growth rates of the output and input factors. $\mathrm{Y}$ is GDP, $\mathrm{L}$ is labor force, $\mathrm{K}$ is physical capital, $\mathrm{H}$ is human capital, and $F$ is the level of financial development. Subscripts $i$ and $t$ denote cross-sections and the time period, respectively. Based on the model presented in equation (1), this study proposes the following empirical model:

$$
G Y_{i t}=\mathrm{f}\left(G L_{i t}, I N V_{i t}, S E C_{i t}, L L Y_{i t}, B A N K_{i t}, \text { PRIVATE }_{i t}\right),(2)
$$

where the growth rate of GDP per capita will be used as the

3 These financial proxies are used by many scholars, e.g. Demirguc-Kunt A, Levine R. Stock Market Development and Financial Intermediaries, The World Bank Economic Review, 10(2), 1995, Levine R. Financial

Development and Economic Growth: Views and Agenda, Journal of Economic Literature, 35(2), 688-726, 1997, Beck T, Levine R, Loayza N. Finance and the Source of Growth, Journal of Financial Economics, 58, 261-300, 2000, and Boyd JH, Levine R, Smith BD. The Impact of Inflation on Financial Sector Performance, Journal of Monetary Economics, 47, 221-48, 2001 . 
dependent variable. Following Levine [28], Levine and Zervos [29], Beck, Demirguc-Kunt [40] studies, this variable is measured as the difference in natural logarithm of the GDP per capita. The first exploratory variable GL is the growth rate of the labour force. The second variable represents the physical capital stock, measured as the ratio of domestic investment to GDP. Denoted as INV. The third variable is the secondary school enrolment that indicated the human capital accumulation and it is abbreviated as SEC.

The fourth, fifth and sixth variable representing financial development are adopted from King and Levine [6]; these variables have also been used extensively in other studies, e.g. Levine [28] and Demirguc-Kunt and Levine [27]. The fourth variable, $L L Y$ is the debt to GDP ratio, also called the M2 to GDP ratio, and is a traditional measure of financial sector development or financial depth. This was proposed by Goldsmith [22] and McKinnon [41] for their analysis of the size of the formal financial intermediary sector related to the economic activity. Liquid liabilities consist of currency outside banks, demand deposits, other than those of the central government, and the time, savings, and foreign currency deposits of resident sectors other than the central government. ${ }^{4}$

The fifth variable $B A N K^{5}$ is the ratio of commercial bank assets divided by commercial bank plus central bank assets [6]. Notably, commercial banks seem more likely to provide the type of risk sharing and information services emphasised in recent theoretical models than central banks. In any case, there are deficiencies with this measure of financial development; banks are not the only financial intermediaries that provide risk management, information acquisition, and monitoring services. Moreover, governments in many countries have a significant influence on banks, so the contrast between banks and central banks may be obscure. Finally, the variable $B A N K$ does not capture to whom the financial system is allocating credit. Nevertheless, by at least partially isolating those financial intermediaries more likely to provide the financial services emphasised in theoretical studies, the use of the $B A N K$ variable can augment and complement the conclusions that can be drawn from using only financial depth, $L L Y$.

The sixth variable, PRIVATE is the ratio of claims on the nonfinancial private sector to total domestic credit (excluding credit to money banks) and is designed to measure domestic asset distribution. It regards the role of the financial system that allocates credit to the government or state-owned enterprises but that may not be evaluating managers, selecting investment projects, pooling risk, and providing financial services to the same degree as financial systems that allocate credit to [6].

Data are collected from IMF's International Financial Statistics (IFS), 2015 and World Bank's World Development

4 LLY corresponds to lines 34 and 35 in the International Monetary Fund's (IMF) International Financial Statistics (IFS).

5 BANK corresponds to lines 12 and 2, a- d, in the International Monetary Fund's (IMF) International Financial Statistics (IFS).
Indicators (WDI), 2015. The raw dataset covers 147 countries for a period of 14 years between 2000 and 2013. The number of countries is limited to 147 out of 216 countries because of limited data availability of financial variables.

\subsection{Estimation Techniques}

In this study, both the static and dynamic panel estimation techniques are used. The reason for using both techniques is to identify the empirical differences in the output. The static panel estimators are inconsistent due to endogeneity issue [42].

The regression equation for the above model is presented as follows:

$$
\begin{gathered}
G Y_{i t}=\alpha_{i}+\gamma_{t}+\beta_{1} G L_{i t}+\beta_{2} I N V_{i t}+ \\
\beta_{3} S E C_{i t}+\beta_{4} L L Y_{i t}+\beta_{5} B A N K_{i t}+\beta_{6} \text { PRIVATE }_{i t}+u_{i t}
\end{gathered}
$$

where $G Y_{i t}$ is country i's $(\mathrm{i}=1, \ldots, \mathrm{N})$ real GDP per capita growth in year $t ; \alpha_{i}$ is an unobserved country effect; and $\gamma_{t}$ is an unobserved time effect.

Among the static panel estimation models, which included fixed and random effect models, we used the fixed effect model in this study. The fixed model is adopted for a number of reasons. First, if any of the explanatory variables are correlated with the unobserved country specific random effects, then the random effects model yields biased and inconsistent estimates of the parameters, whereas the fixed effects estimates are free from this problem [43]. Second, the random effect model is more appropriate when used on a small sample from a large population [43]. In our case, the sample covers a large number the countries in the world which supports our choice of the fixed model in this study. Third, according to Hausman [44] test, the dataset is more suitable to the application of the fixed effect.

The dynamic panel estimation model suggested by Arellano and Bover [23] and Blundell and Bond [24] is applied as the second estimation method. The original Arellano and Bond estimator is a generalised method of moments (GMM) estimator for linear dynamic panel-data models that use lagged levels of the endogenous variables as well as first differences of the exogenous variables as instruments. The Arellano-Bond estimator removes the panel-specific heterogeneity by first-differencing the regression equation. The original Arellano and Bover estimator, difference $G M M$, has been improved to system GMM, by Arellano and Bover [23] and Blundell and Bond [24] in order to eliminate the potential weakness of lagged levels. They modified the model by considering lagged levels as well as lagged differences. In order to capture lagged level of the model, the system GMM is applied in this paper. 


\section{Empirical Results and Discussion}

The aim of this study is to include the largest possible number of observations in order to reflect the general effect of GFC over the economic growth and financial development nexus. Therefore, the sample is not restricted to a balanced panel. Descriptive statistics are summarised in Table 1.

Table 1. Descriptive Statistics

\begin{tabular}{|c|c|c|c|c|}
\hline Variable & Mean & SD & Min & Max \\
\hline GY & 0.0753 & 0.1292 & -1.0317 & 1.3763 \\
\hline INV & 0.2295 & 0.1073 & 0.0000 & 1.4788 \\
\hline SEC & 0.6162 & 0.4200 & 0.0000 & $1.6558^{\mathrm{a}}$ \\
\hline GL & 0.0187 & 0.0214 & -0.1052 & 0.2417 \\
\hline LLY & 0.5694 & 0.3697 & 0.0000 & 2.4779 \\
\hline BANK & 0.8536 & 0.1993 & 0.0000 & 1.0000 \\
\hline PRIVATE & 0.6698 & 0.2857 & 0.0000 & 1.0381 \\
\hline
\end{tabular}

Notes: ${ }^{\text {a }}$ The secondary school enrolment ratio is the ratio of total secondary school enrolment, regardless of age, to the population of the age group that officially corresponds to the level of education shown. As a result, it can occasionally exceed $100 \%$.

The general observations from the results in the tables are that the sample countries experienced extreme volatility in GDP growth rates showing a mean value of GDP per capita growth of approximately $7 \%$ and a standard deviation exceeding $10 \%$ for all the samples. The capital investment represented by INV appeared to be stable, averaging almost $23 \%$ within the sample period, while average labour force growth, GL, shows extremely different results with a mean value of GL of $2 \%$ in the first sample and $7 \%$ in the second sample. In addition, the volatility of GL variable as indicated by the standard deviation is relatively high in the second sample compared to the first sample, which can be explained by the negative GDP per capita rates in some countries, which lead to high volatility. The average of education level is high, while the standard deviation of secondary education enrolment is also high.

The correlation coefficients might contribute to our analysis to understand the relationship between the variables. Table 2 summaries the correlation the variables.

The first observation from Table 2 is that the correlations between the finance proxies are generally low. The exception is the slightly higher correlation coefficient between finance variables of LLY and BANK, and, PRIVATE and BANK. Since there is no direct relationship between these variables, the high correlation is more likely due to the fact that both indicators are part of a larger financial development picture and thus show a similar pattern.

\subsection{Diagnostic Tests}

In order to determine whether the series suffer from nonstationary in panel data, the standard test for unit roots in the series was undertaken. Both the Im-Pesaran-Shin and Fisher-type tests were used. Since the sample is not strongly balanced, Im-Pesaran-Shin does not fit the model. The maximum lag selection is determined based on Schwarz Info Criterion (SIC) and it is reported in Table 3.

The panel unit-root test indicates that all variables of Hypothesis are stationary. The Fisher type unit root test for all variables are reported in Table 4.

Table 2. Correlation Analysis

\begin{tabular}{|c|c|c|c|c|c|c|c|}
\hline Variables & GY & LLY & BANK & PRIVATE & INV & SEC & GL \\
\hline GY & 1.0000 & -0.0984 & 0.0388 & 0.0791 & 0.1411 & -0.0413 & 0.0168 \\
\hline LLY & -0.0984 & 1.0000 & 0.2694 & -0.0934 & 0.0539 & 0.2852 & -0.1476 \\
\hline BANK & 0.0388 & 0.2694 & 1.0000 & 0.2978 & 0.0566 & 0.2417 & -0.1166 \\
\hline PRIVATE & 0.0791 & -0.0934 & 0.2978 & 1.0000 & -0.0168 & 0.0556 & 0.0445 \\
\hline INV & 0.1411 & 0.0539 & 0.0566 & -0.0168 & 1.0000 & 0.0528 & 0.0553 \\
\hline SEC & -0.0413 & 0.2852 & 0.2417 & 0.0556 & 0.0528 & 1.0000 & -0.2371 \\
\hline GL & 0.0168 & -0.1476 & -0.1166 & 0.0445 & 0.0553 & -0.2371 & 1.0000 \\
\hline
\end{tabular}

Table 3. Summary of SIC Values

\begin{tabular}{|c|c|c|c|c|}
\hline & L0 & L1 & L2 & L3 \\
\hline GY & $-2,762.26$ & $-2,776.07^{*}$ & $-2,704.88$ & $-2,571.08$ \\
\hline LLY & $-2,038.63$ & $-3,579.31$ & $-3,633.20^{*}$ & $-3,269.84$ \\
\hline BANK & $-1,864.43$ & $-3,134.57^{*}$ & $-3,057.76$ & $-2,724.32$ \\
\hline PRIVATE & -768.83 & $-2,840.70$ & $-3,793.17^{*}$ & $-3,494.74$ \\
\hline INV & $-5,427.12$ & $-5,901.46^{*}$ & $-5,535.34$ & $-5,138.91$ \\
\hline GL & $-11,927.23^{*}$ & $-11,461.24$ & $-10,684.60$ & $-9,883.78$ \\
\hline SEC & 62.96 & $-137.37^{*}$ & -91.53 & -45.07 \\
\hline
\end{tabular}

Note: $\mathrm{L}$ is the length of each lag; all values are given to four decimal places; * indicates the best model. 
Table 4. Fisher Type Unit Root Test

\begin{tabular}{|c|c|c|}
\hline Variable & Statistic & Probability \\
\hline GY & -16.8261 & 0.0000 \\
\hline LLY* & 5.6925 & 1.0000 \\
\hline BANK & -3.2769 & 0.0005 \\
\hline PRIVATE & -2.5744 & 0.0050 \\
\hline INV & -3.0481 & 0.0012 \\
\hline GL & -7.4739 & 0.0000 \\
\hline SEC & -2.1550 & 0.0156 \\
\hline dLLY & -4.6698 & 0.0000 \\
\hline
\end{tabular}

Note: Fisher Type Unit Root Test statistics: $H_{0}$ : unit root (non-stationary), $H_{1}$ : no unit root(stationary); t-statistics are presented in parenthesis.

\subsection{Estimations Output and Discussion}

Hausman [44] test was conducted in order to decide which effect, fixed effect or random effect, is relevant to the sample data. Table 5 illustrates the output of this analysis.

Table 5. Hausman Specification Test

\begin{tabular}{|c|c|c|c|c|}
\hline & (b) & (B) & (b-B) & $\operatorname{sqrt}\left(\operatorname{diag}\left(\mathrm{V} \_b-\mathrm{V} \_\mathrm{B}\right)\right)$ \\
\hline & FE & RE & Difference & S.E. \\
\hline LLY & -0.0297 & -0.0101 & -0.0196 & 0.0184 \\
\hline BANK & 0.0520 & 0.0344 & 0.0176 & 0.0117 \\
\hline PRIVATE & 0.0875 & 0.0517 & 0.0358 & 0.0139 \\
\hline PRIVY & -0.0745 & -0.0463 & -0.0282 & 0.0129 \\
\hline INV & 0.2665 & 0.1735 & 0.0930 & 0.0347 \\
\hline SEC & 0.0078 & -0.0012 & 0.0091 & 0.0085 \\
\hline GL & -0.2863 & -0.1396 & -0.1467 & 0.1607 \\
\hline \multicolumn{5}{|c|}{$\begin{aligned} \text { Chi2 } 2(7) & =(b-B)^{\prime}\left[\left(V_{-} b-V_{-} B\right)^{\wedge}(-1)\right](b-B) \\
& =24.20\end{aligned}$} \\
\hline
\end{tabular}

Notes: $\mathrm{b}=$ consistent under Ho and Ha; obtained from xtreg,

$\mathrm{B}=$ inconsistent under Ha, efficient under Ho; obtained from xtreg* Test: Ho: difference in coefficients not systematic

*Xtreg refers to estimation method to analyse fixed-, between-, and random-effects, and population-averaged linear models.
The hypothesis is analysed for fixed effect and dynamic panel model for pre and post GFC period. There are four different outputs for the hypothesis, reported in Table 6 to Table 9 respectively. In order to capture the post GFC period effect, the post GFC dummy variable is used. The post GFC dummy variable is calculated by a time dummy variable $d L L Y$ (being 1 for the period after 2008 and zero otherwise), which is multiplied by each financial development proxies

Table 6 indicates that all financial proxies are significant at the $95 \%$ level in the fixed effect model. Although BANK and PRIVATE have a positive effect, dLLY has a negative effect on GDP per capita growth. The explanatory power of dLLY on GDP has been diminished by the mid-1990s. Friedman and Kuttner [45] and Estrella and Mishkin [46] assert that the relationship between M2 and GDP weakened and deteriorated because the money aggregate indicator does not perform as an information variable, which is an indicator of policy actions and instrument from a policy perspective. Therefore, a negative value of the coefficient for dLLY shows that dLLY does not have a positive effect on the GDP per capita growth. Investment, INV, is also positive and significant as a result of the fixed effect analysis while SEC and GL are not significant in this model. One reason that SEC was found insignificant could be that SEC is not an effective measurement of education because it does not explain the in-depth education level which contributes to the economic growth at a significant level. GL was expected to be positive and significant in these models, however, none of the coefficients for this variable is significant. The potential reason for this could be the fact that labour force variable does not necessarily reflect working people due to the effect of unemployment. Since the sample time period consists of the largest financial crisis, the labour force growth effect might be offset by higher unemployment.

Table 6. Estimation Output of Fixed Effect Model

\begin{tabular}{|c|c|c|c|c|c|c|}
\hline \multicolumn{2}{|c|}{ Dependent Variable GY } & & & & \\
\hline Variable & 1 & & 2 & & & \\
\hline dLLY & -0.130 & $(0.000)$ & & & & \\
\hline BANK & & & 0.062 & $(0.001)$ & & $(0.002)$ \\
\hline PRIVATE & & & & & 0.043 & $(0.000)$ \\
\hline INV & 0.230 & $(0.000)$ & 0.264 & $(0.000)$ & 0.263 & $(0.267)$ \\
\hline SEC & 0.017 & $(0.136)$ & 0.011 & $(0.329)$ & 0.013 & $(0.390)$ \\
\hline GL & -0.050 & $(0.814)$ & -0.167 & $(0.432)$ & -0.183 & \\
\hline
\end{tabular}

Note: First numbers are coefficients and numbers in brackets are p-values

Table 7. Estimation Output of Fixed Effect Model with Post GFC Dummy Variable

\begin{tabular}{|c|c|c|c|c|c|c|}
\hline \multicolumn{2}{|c|}{ Dependent Variable GY } & & & & \\
\hline Variable & 1 & & 2 & & 3 & \\
\hline dLLY & -0.119 & $(0.002)$ & & & & \\
\hline BANK & & & 0.088 & $(0.000)$ & & $(0.000)$ \\
\hline PRIVATE & & & & & 0.070 & $(0.000)$ \\
\hline GFC.DUMMY & -0.020 & $(0.700)$ & -0.050 & $(0.000)$ & -0.062 & $(0.000)$ \\
\hline INV & 0.230 & $(0.000)$ & 0.253 & $(0.000)$ & 0.249 & $(0.290)$ \\
\hline SEC & 0.016 & $(0.137)$ & 0.011 & $(0.318)$ & 0.012 & $(0.226)$ \\
\hline GL & -0.052 & $(0.808)$ & -0.214 & $(0.306)$ & -0.253 & $(25)$ \\
\hline
\end{tabular}

Note: First numbers are coefficients and numbers in brackets are p-values. 
In Table 7, the output of the fixed effect estimation with the post GFC dummy variable indicates that most of the financial proxies are significant at the $95 \%$ level. The only exception is the post GFC dummy variable of dLLY, first difference of liquid liabilities, which is not significant in this model. The variables BANK and PRIVATE actually explain the expected findings regarding the effect of the GFC on GDP growth. While the coefficient of BANK was 0.062 in the fixed effect model without dummy variables, it increased to 0.088 in the model with post GFC dummy variable. The coefficient of post GFC dummy variable of BANK indicates -0.050 . The same consequences are applicable for the PRIVATE. While the coefficient of PRIVATE was 0.043 in Table 6 , then, in Table 7 , it increased to 0.070 in the model with post GFC dummy variable and the coefficient of post GFC dummy variable of PRIVATE was -0.062 . Both the variable BANK and PRIVATE support the main argument of the paper and indicate that after the GFC, the positive relationship between financial proxies and GDP per capita growth turned to negative as a consequence of the effects of the crisis. The destructive effect of the GFC on BANK and PRIVATE was absorbed and indicated by the GFC.DUMMY.

The output of the dynamic panel model in Table 8 illustrates that most of the financial proxies are significant at the $95 \%$ level. Among financial proxies, PRIVATE is positive but not significant, which is not able to explain its effect on GDP growth. Obviously, liquid liabilities, dLLY, is significant and negative, which indicates that supplying money into the market does not have positive contribution to recover from the crisis in the period 2000-2013. The second financial variable, BANK, which denotes the ratio of deposit money bank domestic assets to deposit money bank domestic assets plus central bank domestic assets, is positive and significant. This indicates that a higher level of domestic bank and central bank assets positively contributes to the GDP per capita growth before and after the crisis. As expected, investment is positive and significant. SEC is only significant in the first phase, which is explained before it can be caused by the inefficiency of this variable. Contrary to the fixed effect model, labour force, GL, is significant and positive in panel data except for the first phase. It indicates that a higher level of labour force positively affects GDP per capita growth. This difference actually confirms that the panel data model is a better estimation method to analyse economic growth.

Table 9 presents the output of the panel data with the post GFC dummy variable and provides a richer insight on the effect of the GFC on the economy. The dummy variable helps to identify the determined term both pre and post the GFC period. The expected output was that the negative effect of the crisis will be borne by the post GFC dummy variable. BANK and PRIVATE confirm the expected results. However; the liquid liabilities, dLLY is negative and significant, its post GFC dummy variable is negative but not significant. In essence this result indicates that the effect of liquid liabilities is not clear during the crisis; domestic bank and central bank assets had positive effect before the crisis and the effect turned to negative following the GFC; the variable PRIVATE, which denotes credit allocation to the private enterprises, had also a positive effect but it is not significant, the post GFC dummy variable of PRIVATE is negative and significant. The effect of PRIVATE is ambiguous before the crisis; however, the effect turned to negative following the GFC.

Table 8. Estimation Output of Dynamic Panel Model

\begin{tabular}{|c|c|c|c|c|c|c|}
\hline \multicolumn{3}{|c|}{ Dependent Variable GY } & & & \\
\hline Variable & 1 & & 2 & & 3 & \\
\hline GY(-1) & 0.024 & $(0.290)$ & 0.023 & $(0.311)$ & 0.025 & $(0.279)$ \\
\hline dLLY & -0.145 & $(0.000)$ & & & & \\
\hline BANK & & & 0.114 & $(0.001)$ & & $(0.537)$ \\
\hline PRIVATE & & & & & 0.025 & $(0.000)$ \\
\hline INV & 0.290 & $(0.000)$ & 0.281 & $(0.000)$ & 0.287 & $(0.077)$ \\
\hline SEC & 0.029 & $(0.044)$ & 0.022 & $(0.140)$ & 0.026 & $(0.055)$ \\
\hline GL & 0.442 & $(0.127)$ & 0.611 & $(0.037)$ & 0.564 & \\
\hline
\end{tabular}

Note: First numbers are coefficients and numbers in brackets are p-values.

Table 9. Estimation Output of Dynamic Panel Model with the Post GFC Dummy Variable

\begin{tabular}{|c|c|c|c|c|c|c|}
\hline \multicolumn{3}{|c|}{ Dependent Variable GY } & & & & \\
\hline Variable & 1 & & 2 & & 3 & \\
\hline GY(-1) & 0.024 & $(0.302)$ & -0.113 & $(0.000)$ & -0.111 & $(0.000)$ \\
\hline dLLY & -0.149 & $(0.001)$ & & & & \\
\hline BANK & & & 0.151 & $(0.000)$ & & \\
\hline PRIVATE & & & & & 0.069 & $(0.076)$ \\
\hline GFC.DUMMY & -0.011 & $(0.855)$ & -0.120 & $(0.000)$ & -0.143 & $(0.000)$ \\
\hline $\mathrm{INV}$ & 0.290 & $(0.000)$ & 0.220 & $(0.001)$ & 0.219 & $(0.001)$ \\
\hline SEC & 0.029 & $(0.046)$ & 0.013 & $(0.361)$ & 0.014 & $(0.328)$ \\
\hline GL & 0.437 & $(0.131)$ & 0.337 & $(0.232)$ & 0.278 & $(0.326)$ \\
\hline
\end{tabular}

Note: First numbers are coefficients and numbers in brackets are p-values. 


\section{Concluding Remarks}

We present the relationship between the financial development and the economic growth before and after the GFC. The relationship has been revisited by using the fixed effect and dynamic panel data estimations to draw implications for economic management and future research. The analysis utilisied data from 147 countries for the period between 2000 and 2013. The aim of this paper was to empirically investigate the effect of GFC on the relationship between the traditional financial development proxies and economic growth.

The findings indicate that the GFC had a significant impact on the relationship between financial development and economic growth. This was clearly verified from both the fixed effect and the panel data estimation results.

The empirical findings without post GFC dummy variable indicated that there is a strong relationship between the financial development and the economic growth for the period 2000-2013. The exception is liquid liabilities to GDP ratio, dLLY, is negative in both estimators, while the other two financial proxies are positive. This indicates that in the time of crisis, the rapid growth of money supply does not induce the same rapid growth in real economy. The traditional approach to explain the role of financial development in channeling economic growth has been hampered by GFC. A possible reason for this broken relationship might be explained by the negative expectations of investors which is the result of the uncertainty in the economic environment after GFC. Policy makers should aim to improve the market sentiment through policy measures that will aim to long term economic stability within a global interrelated economic system. This will allow investors to make long term investment planning with greater reliability on the stability of the economic system.

Furthermore, the empirical findings with the use of the post GFC dummy variable are again unclear with regards to the impact of the liquid liabilities to GDP variable. It is insignificant for the period after the crisis in both the fixed effect and the panel data estimation results. The other two financial proxies with post GFC dummy variable have clearly demonstrated the effects of the GFC. These have a positive and significant relationship before the crisis and a negative and significant relation after the crisis.

In terms of comparing the two estimation techniques, the dynamic panel data results are stronger than the results of the fixed effect technique. This confirms that the dynamic panel data technique is a more appropriate method when aiming to analyse the economic growth, which entails a dynamic process and also allows for control of potential simultaneity and endogeneity in the analysis.

Our analysis has focused on the short term analysis of GFC effect on financial development and economic growth nexus, we leave aside the question whether the destructive effect of the GFC persist on real economy in long term. Also, future studies might apply simultaneous equations to further explore the dual causality of relationship between financial development and economic growth.

\section{REFERENCES}

[1] Bagehot W. Lombard Street: A description of the Money Market, Scribner, Armstrong \& Company, Canada, 1873

[2] Schumpeter JA. The Fundamental Phenomenon of Economic Development, American Journal of Economics and Sociology, 61(2), 405-37, 1911

[3] Robinson J. The Rate of Interest and Other Essays, MacMillan, London, 1952

[4] Gelb AH. Financial Policies, Growth and Efficiency The World Bank Working Papers, 202, 1989

[5] Greenwood J, Jovanovic B. Financial Development, Growth, and the Distribution of Income, Journal of Political Economy, 98(5), 1076-107, 1990

[6] King RG, Levine R. Finance and Growth: Schumpeter Might be Right, The Quarterly Journal of Economics, 108(3), 717-37, 1993

[7] Levine R. Finance and Growth: Theory and Evidence, NBER Working Paper, 10766, 2004

[8] Levine R. Financial Structure and Economic Development, International Finance Discussion Papers, 381, 1-43, 1990

[9] Rioja F, Valev N. Does one size fit all?: A Reexamination of the Finance and Growth Relationship, Journal of Development Economics, 74(2), 429-47, 2004

[10] Bahadir B, Valev N. Financial Development Convergence, Journal of Banking \& Finance, 56, 61-71, 2015

[11] Aydin M, Malcioglu G. Financial Development and Economic Growth Relationship: The Case of OECD Countries, Journal of Applied Research in Finance and Economics, 2(1), 1-7, 2016

[12] Musta E. Financial Development Influence on Economic Growth in Albania, International Editorial and Advisory Board, 59, 2016

[13] Kılınç D, Seven Ü, Yetkiner H. Financial Development Convergence: New Evidence for the EU, Central Bank Review, 17(2), 47-54, 2017

[14] IMF. World Economic Outlook Report, 2015

[15] Almunia M, Benetrix A, Eichengreen B, O’Rourke KH, Rua G. From Great Depression to Great Credit Crisis: Similarities, Differences and Lessons, Economic Policy, 25(62), 219-65, 2010

[16] Claessens S, Ayhan-Kose M, Terrones ME. The Global Financial Crisis: How Similar? How Different? How Costly?, Journal of Asian Economics, 21(3), 247-64, 2010

[17] EMU. Economic Crisis in Europe: Causes, Consequences and Responses. Luxembourg; 2009. 
[18] Akyüz Y. Policy Response to the Global Financial Crisis: Key Issues for Developing Countries, South Centre Research Paper, 24, 2009

[19] Crotty J. Structural Causes of the Global Financial Crisis: A Critical Assessment of the 'New Financial Architecture', Cambridge Journal of Eeconomics, 33(4), 563-80, 2009

[20] Dungey M, Dwyer GP, Flavin T. Systematic and Liquidity Risk in Subprime-Mortgage Backed Securities, Open Economies Review, 24(1), 5-32, 2013

[21] Luchtenberg KF, Vu QV. The 2008 Financial Crisis: Stock Market Contagion and its Determinants, Research in International Business and Finance, 33, 178-203, 2015

[22] Goldsmith RW. Financial Structure and Development, Yale University Press, New Haven, 1969

[23] Arellano M, Bover O. Another Look at the Instrumental-Variable Estimation of Error Component Models, Journal of Econometrics, 68(1), 29-51, 1995

[24] Blundell R, Bond S. Initial Conditions and Moment Restrictions in Dynamic Panel Data Models, Journal of Econometrics, 87, 115-43, 1998

[25] Lucas RE. On The Mechanics of Economic Development, Journal of Monetary Economics, 22, 3-42, 1988

[26] Bencivenga VR, Smith BD. Some Consequences of Credit Rationing in an Endogenous Growth Model, Journal of Economic Dynamics and Control, 17, 97-122, 1993

[27] Demirguc-Kunt A, Levine R. Stock Market Development and Financial Intermediaries, The World Bank Economic Review, 10(2), 1995

[28] Levine R. Financial Development and Economic Growth: Views and Agenda, Journal of Economic Literature, 35(2), 688-726, 1997

[29] Levine R, Zervos S. Stock Markets, Banks and Economic Growth, The American Economic Review, 88(3), 537-58, 1998

[30] Jailani MZ, Masih M. Determining the Relationship Between Financial Development and Economic Growth: An Application of ARDL Technique to Singapore, 2015

[31] Beck T, Levine R, Loayza N. Finance and the Source of Growth, Journal of Financial Economics, 58, 261-300, 2000
[32] Boyd JH, Levine R, Smith BD. The Impact of Inflation on Financial Sector Performance, Journal of Monetary Economics, 47, 221-48, 2001

[33] Arrow KJ. The Economic Implications of Learning by Doing, The Review of Economic Studies, 29(3), 155-73, 1962

[34] Uzawa H. Optimal Technical Change in an Aggregative Model of Economic Growth, International Economic Review, 6(1), 18-31, 1965

[35] Sheshinski E. Optimal Accumulation with Learning by Doing, Essays on the Theory of Optimal Economic Growth, 31-52, 1967

[36] Romer PM. Increasing Returns and Long-Run Growth, The Journal of Political Economy, 94(5), 1002-37, 1986

[37] Rebelo S. Long-Run Policy Analysis and Long-Run Growth, The Journal of Political Economy, 99(3), 500-21, 1991

[38] Barro RJ, Martin XS-i. Economic Growth, The IMT Press, 2004

[39] Odedokun MO. Alternative Econometric Approaches for Analysing the Role of the Financial Sector in Economic Growth, Journal of Development Economics, 50, 119-46, 1996

[40] Beck T, Demirguc-Kunt A, Levine R, Maksimovic V. Financial Structure and Economic Development Firm, Industry, and Country Evidence: World Bank; 2000.

[41] McKinnon RI. Money and Capital in Economic Development, Brookings Institution, Washington, 1973

[42] Antonakis J, Bendahan S, Jacquart P, Lalive R. Causality and Endogeneity: Problems and Solutions, The Oxford handbook of leadership and organizations, (93-117), 2014

[43] Baltagi B. Economic Analysis of Panel Data, John Wiley and Sons, Chippenham., 2005

[44] Hausman JA. Specification Tests in Econometrics, Econometrica, 46(6), 1251-71, 1978

[45] Friedman BM, Kuttner KN. Money, Income, Prices, and Interest Rates, American Economic Review, 82, 472-92, 1992

[46] Estrella A, Mishkin FS. Is There A Role for Monetary Aggregates in the Conduct of Monetary Policy?, NBER Working Paper, 5845, 1996 